\title{
Contamination assessment of mine infrastructure areas for closure and relinquishment: Hazelwood Coal Mine, Victoria, Australia
}

TR Weaver Environmental Resources Management Australia Pty Ltd, Australia

PS Fridell Environmental Resources Management Australia Pty Ltd, Australia

MB Ospina Environmental Resources Management Australia Pty Ltd, Australia

R Brooker ENGIE Australia Pty Ltd, Australia

MK Schenkel ENGIE Australia Pty Ltd, Australia

AM Scrase ENGIE Australia Pty Ltd, Australia

\begin{abstract}
The Hazelwood coal mine and power station, near Morwell in the Latrobe Valley, Victoria, ceased operation in March 2017. A water filled mine void with potential for recreational, agricultural, commercial and industrial uses is envisioned for the surrounding area following mine licence relinquishment. Critical to achieving this is the assessment and management of infrastructure and potential contamination that is present in the mine licence area. This paper presents the approach to this assessment so that land management options and, if necessary, remediation can be identified and implemented early in the rehabilitation project.
\end{abstract}

In Victoria, the Environmental Protection Agency (EPA) is the lead agency for land and water pollution; Department of Jobs, Precincts and Regions (DJPR) leads the mine rehabilitation process. These processes run in parallel, influencing each other. For the mine void the owner, ENGIE, has implemented a strategy that is consistent with EPA requirements, removing most equipment whilst leaving some in place. Infrastructure surrounding the mine, including conveyors, ash and water pipelines, and lay-down yards is being addressed through principles aligning with the National Environment Protection (Assessment of Site Contamination) Measure (ASC NEPM) contaminated site assessment approach, in parallel with mine closure and rehabilitation requirements. A preliminary site investigation (PSI) is underway that is based on former operational and sub-catchment areas and which includes a comprehensive history of former site activities and environmental condition. A key challenge at Hazelwood is the scale. The pit perimeter is over $16 \mathrm{~km}$ and the mine license area exceeds 1,200 ha. Former activities in and around the mine include: coal and coal ash handling; coal ash, hard rubbish and asbestos disposal; fuel storage and handling; pipe works, and surrounding commercial, industrial, and agricultural activities.

The PSI will identify the likely level of contamination so that some areas may be able to be excised from further works while others move to detailed site investigation (DSI) and, if necessary, remediation. A sub-catchment approach to sub-areas allows source-pathway-receptor conceptual site models to be developed that are consistent with the NEPM regardless of whether areas progress to DSI and remediation stages, or are closed out at PSI stage.

Keywords: mine closure, infrastructure, contamination

\section{Introduction}

The assessment and evaluation of potential risks associated with soil and/or water contamination as mine sites close poses specific challenges to the rehabilitation and relinquishment of mines and their surrounding areas. In many jurisdictions, the assessment of potential risks that may be associated with the status of soil 
and/or water contamination is led by regulators other than those who have been the lead agency for the mine during operations; associated with this, specific environmental policies and guidelines may become relevant as the site progresses through closure. The types of assessments also differ from those that may have been undertaken during the operational period of the mine when water and soils would have been managed through instruments such as site-specific environment management plans. During closure, a broader and different suite of analytes and parameters will likely need assessment, as will the full range of locations, operations, and areas of the site as the site progresses through closure to ultimate relinquishment.

The Hazelwood Mine in Victoria (Figure 1) forms part of the Hazelwood Power Complex, which ceased generating power on 31 March 2017. Although depressurisation and earthworks at the mine continue as part of its rehabilitation. Mining at Hazelwood began in 1955, delivering coal to Morwell Briquettes and, from 1964, the Hazelwood Power Station. The entire site, including areas located within, and outside of, the mine licence area, is undergoing closure. The plan for ultimate relinquishment may, depending on the area, include land uses such as industrial, commercial, agricultural, recreational or open space; the mine void is intended to be filled with water, potentially for public recreational use.

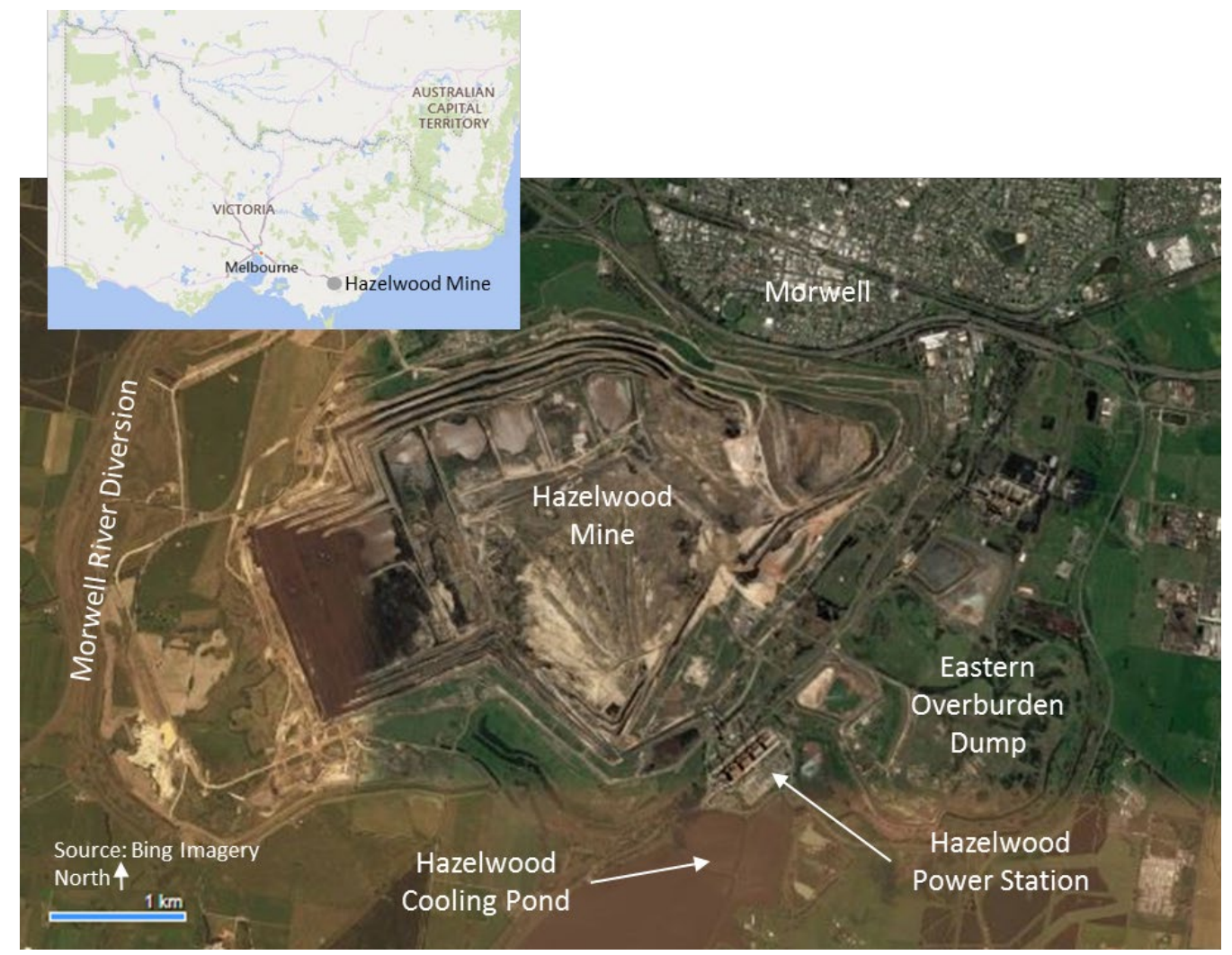

Figure 1 Hazelwood Mine area showing key features

Challenges at the Hazelwood Mine include its scale and proximity to the community. The perimeter of the Hazelwood Mine is over $16 \mathrm{~km}$ and the mine license area is greater than 1,200 ha. The northern edge of the mine is located a few hundred metres south of the Princes Highway and the town of Morwell, which had a population of over 13,770 people in 2016 (Australia Bureau of Statistics (ABS) 2016). The town of Churchill is located approximately $5 \mathrm{~km}$ to the southeast of the mine.

Former activities and associated infrastructure in, and around, the mine are varied. Coal and coal ash handling; fuel storage and handling; and industrial facilities including power generation and contractors' yards are located around the mine footprint. Pipe works including groundwater, fire water, ash and ash water transfer; groundwater depressurisation, transfer and storage infrastructure, and disposal of ash, asbestos and hard rubbish are also present within and around the mine. Several of these activities continue. Staff offices and amenities remain onsite to support the mine rehabilitation process, with activities including stabilisation, environmental assessment, decontamination, demolition works, and infrastructure removal 
programs in progress. Other land uses around the mine include land leased for pasture, and areas set aside for drainage, river diversions, and commercial use. Overburden dumps and licenced ash and other landfills are located in the mine licence area; an ash landfill and overburden dumps are also located inside the mine footprint.

In Australia, each state has state-based environmental and mining regulations. In Victoria, the Environment Protection Agency (EPA) is the lead agency for the prevention, management and cleanup of land and water pollution. The Department of Jobs, Precincts and Regions (DJPR) is the lead agency for the regulation of the mining industry, including closure planning and rehabilitation. EPA is also the lead agency for the ash, asbestos and hard rubbish landfills that are located on the mine licence. During closure of the Hazelwood Mine, processes led by each agency are running in parallel and consequently influence each other. To meet EPA objectives regarding the assessment of potentially contaminated land, and as a critical step towards relinquishment, ENGIE is completing a preliminary site investigation (PSI) of all of the areas in and surrounding the mine licence. The results of the PSI will inform aspects of the Hazelwood Mine Rehabilitation and Closure Plan (RCP) including, through the EPA-led assessment processes, potential limitations to end land uses that are presented in the RCP. The RCP is a requirement of DJPR. At the same time as the PSI is underway for the mine licence area, the landfills, which are variably rehabilitated, undergoing closure, or continuing to operate, are being managed by ENGIE through the process described in the Landfill Best Practice Environmental Management (EPA Victoria 2015).

The PSI for the Hazelwood Mine needs to satisfy EPA Victoria requirements, while also providing information required for the RCP. As well as meeting the regulatory requirements, ENGIE has an objective of identifying areas of land where previous contamination is such that the land may be able to be relinquished earlier with little further assessment or rehabilitation works required. This paper presents the approach to this assessment so that land management options and, if necessary, remediation can be identified and implemented early in the rehabilitation project.

\section{$2 \quad$ Method and data}

The scale of the Hazelwood Mine and surrounding areas, together with its proximity to sensitive receptors including the township of Morwell and nearby waterways and agricultural land, is such that a single PSI report would not be a manageable document. Consequently, the Hazelwood Mine and Power Station has been divided into investigation areas for the purpose of the PSI. The initial differentiation is between those areas located within the mine licence and those located outside. The key features located outside the mine licence include; the Hazelwood Cooling Pond, the Integrated Ash Effluent System that transports saline water away from the site, the Hazelwood Power Block, and parts of the Morwell River Diversion. Within the mine licence area are the mine and supporting services, surrounding agricultural land, overburden dumps, spoil mounds from the river diversion, and the EPA-licenced landfills.

The PSI for the assessment of contamination at the mine and associated areas is based on the approach presented in the National Environment Protection (Assessment of Site Contamination) Measure (ASC NEPM) (Commonwealth of Australia 1999). Specific areas identified in the PSI will be followed by a detailed site investigation (DSI), if conditions indicate the need for further assessment. The ASC NEPM recommends assessing potential site contamination in the conceptual framework of linkages between sources, pathways and receptors (SPR). Consequently, a preliminary SPR framework was considered when selecting investigation areas. Where practical, receiving catchments and sub-catchments contributed to the definition of investigation areas as, for much of the area, these are also the potential environmental receptors. This represents a slightly different approach from that taken for the RCP at the Hazelwood Mine which is divided into domains based predominantly on operational history and activities rather than receiving environment. The likely sources, pathways and receptors identified at and in the vicinity of the Hazelwood Mine are shown in Figure 2.

The objective of the PSI of each investigation area is to provide an initial indication of primary sources of contamination, contaminants of potential concern, and potential receptors. This is based on site history and, 
from the site history and investigations completed to date, the potential for pathways between those sources and receptors to be complete is assessed. Incomplete linkages (Figure 2) occur where contaminants are not present at the site in soil or water or, if contaminants are present, where the pathway between the contaminant and the potential receptor is not complete. Where SPR linkages are potentially complete, further assessment (e.g. DSI) may be required. If SPR linkages are incomplete, the PSI may represent the final stage of assessment required.

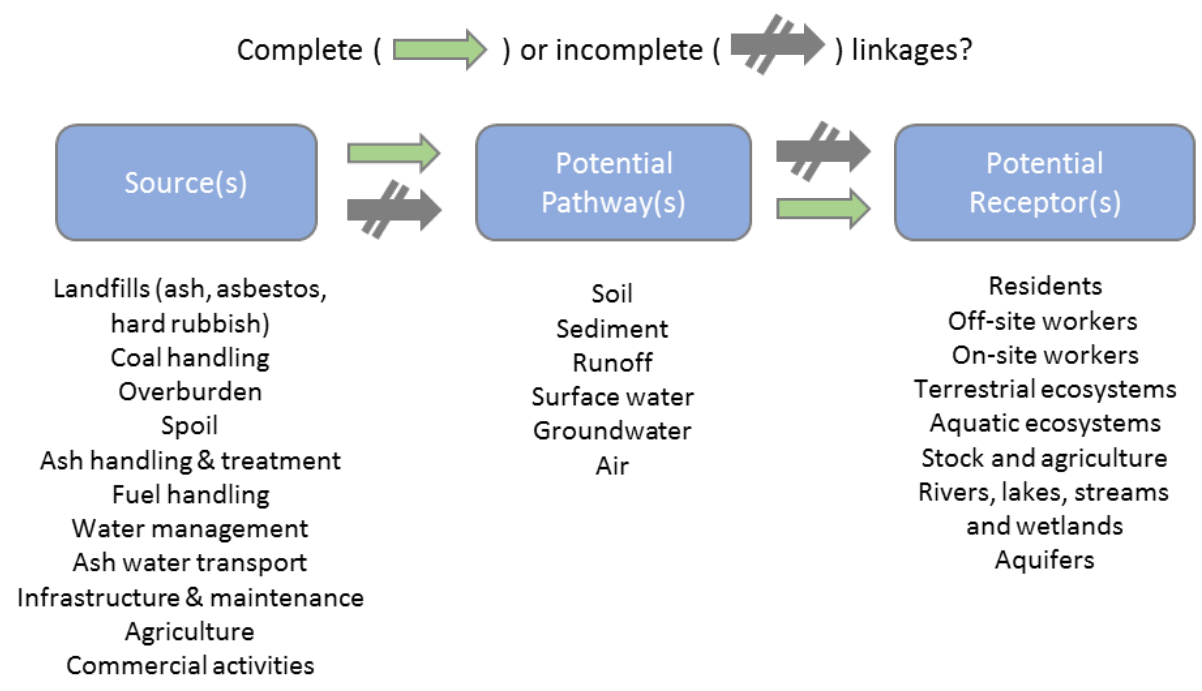

Figure 2 Source-pathway-receptor approach underpinning the preliminary site investigation in each investigation area

With respect to assessing potential sources, the principles included in the Department of Sustainability and Environment (DSE) Practice Note for Potentially Contaminated Land (DSE 2005) were applied. This approach supports the identification of current and former activities with a low, medium, or high potential for contamination to have occurred and investigation areas at the site were initially assessed in this context based on an initial site history and site walkover.

Ten investigation areas were identified using this approach, as shown in Figure 3. Of these areas, the areas surrounding the mine were divided by: 1 ) catchment or sub-catchment; and 2) by the extent to which site history and an initial site inspection indicates that potentially contaminating activities may have occurred. With respect to catchments, areas where runoff could flow towards the Morwell River or its tributary, Eel Hole Creek to the west and south of the site respectively, compared to those where runoff would have a component of flow towards Bennett's Creek, to the east of the site were identified and, in most cases incorporated into different investigation areas. The mine void was considered separate from the other areas.

Those areas within the Morwell River catchment that were considered to have a low potential for contamination (e.g. offsite agricultural and conservation areas) based on the approach presented in DSE (2005) have been combined (i.e. Area 7) due to the potential for these areas to require minimal further assessment beyond the PSI. Using the same approach, an area of substantial industrial activity (e.g. fuel handling, coal and ash handling, and extensive contractor activities) is located to the south of the mine and is treated separately (Area 1). This is also where the bulk of demolition associated with mining infrastructure will occur so timing of intrusive investigations in this area will be linked to demolition activities. Where potentially contaminating activities (e.g. small substations, contractors yards, pump stations) have occurred in investigation areas that are otherwise considered likely to have a low potential for contamination (e.g. agricultural and river diversion spoil mounds), these have been identified as specific sub-areas. Using this approach, the objective is to progress the areas with low potential for contamination towards the end goal of relinquishment while allowing targeted further assessment to occur in specific areas. 


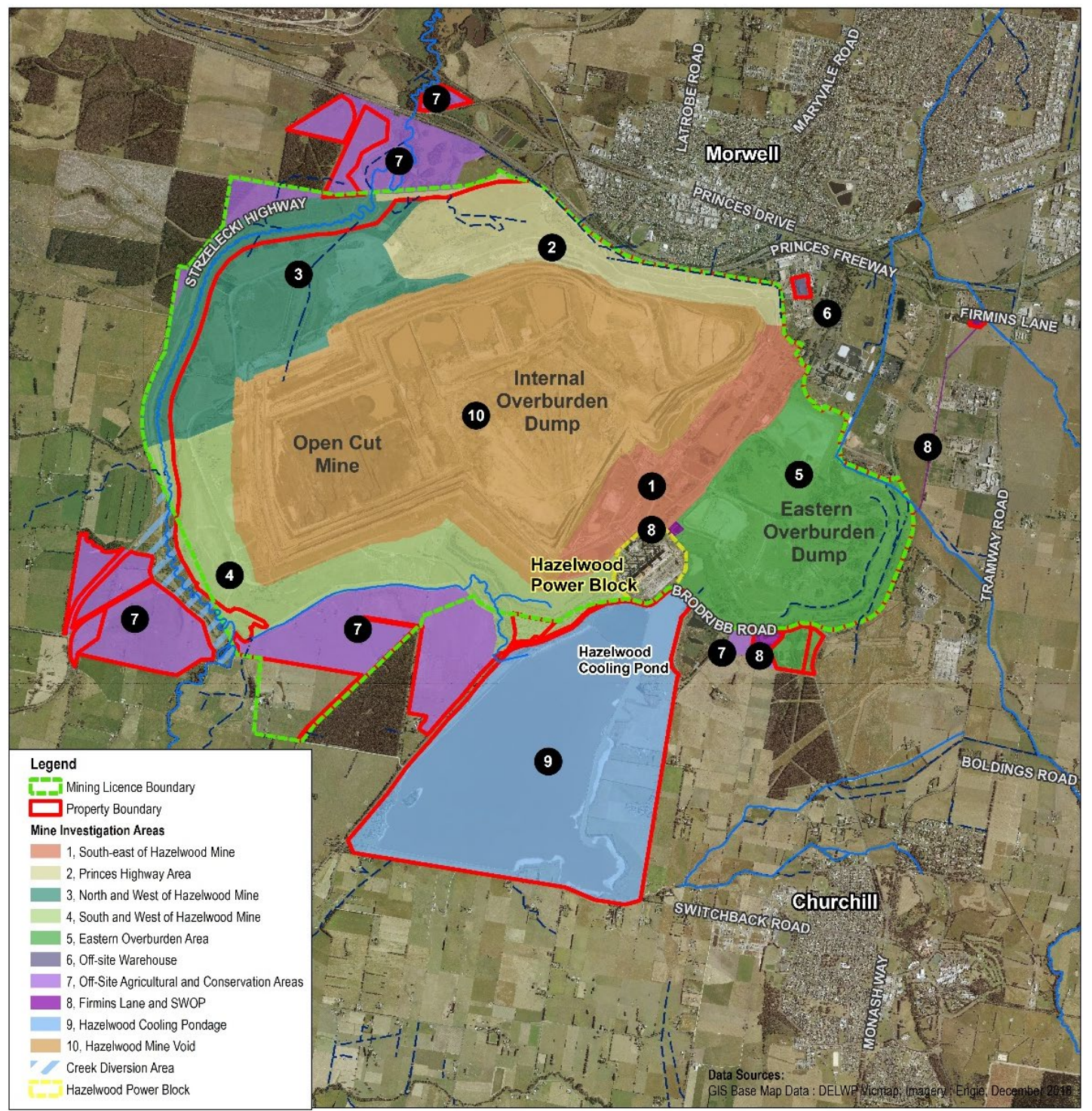

Figure 3 Investigation areas for the Hazelwood Mine preliminary site investigation (PSI) based on prior and current land use and catchments

\section{Preliminary results}

The PSI for the mine licence areas is underway. The scale of the site has been addressed by dividing the site into multiple investigation areas, with consideration of the receiving environment to facilitate assessment of complete, or incomplete, linkages between sources, pathways and potential receptors in the receiving subcatchments and catchments.

The results of site inspections, interviews, and reviews of site history and background information have typically supported the differentiation of specific investigation areas based on land use. Areas where site activities have been limited to agricultural activities and the placement of spoil mounds from river and creek diversions are likely to require only targeted and very limited, if any, intrusive soil, surface water, and/or groundwater sampling to test the findings of the PSI. In other areas, an approach that moves into the DSI stage is likely to be required. This is particularly the case where fuel handling and other industrial activities have occurred. However, based on the review to date, in many areas, contamination sources may be fewer than were previously expected compared to other mine sites. This is due in part to pumps, conveyors and other infrastructure being powered by electricity rather than diesel or fuel oils. Consequently, the use of fuels and oils across the site appears to have been less than at other sites where electricity was not as readily available. 


\section{Conclusion}

The PSI continues; and separating areas by catchment has allowed potential environmental receptors to be more readily defined, allowing consolidated discussion of key areas with respect to potential impacts to surface water, associated ecosystems, and groundwater. As decontamination and demolition of substantial infrastructure progresses at the site, intrusive works will be able to be carried out as part of a DSI. Where required, these works will target specific areas and contaminants as identified in the PSI. However, based on the limited historical land use in several of the investigation areas, the PSI may provide sufficient environmental assessment of those areas to indicate that linkages between sources pathways and receptors are not complete. Under these conditions, the results of the PSI would form the basis of the works to close out those areas at PSI stage and develop a path to relinquishment.

\section{References}

Australian Bureau of Statistics (ABS) 2016, Morwell, ABS Census QuickStats, viewed 30 March 2019, https://quickstats.censusdata.abs.gov.au/census_services/getproduct/census/2016/quickstat/SSC21757

Commonwealth of Australia 1999, National Environment Protection (Assessment of Site Contamination) Measure 1999.

Department of Sustainability and Environment (DSE) 2005, Potentially Contaminated Land, General Practice Notice, June 2005.

Environmental Protection Agency (EPA) Victoria 2015, Siting, Design, Operation and Rehabilitation of Landfills, Best Practice Environmental Management (BPEM), Publication 788.3, August 2015. 